\title{
ON THE HERITABILITY OF SUPERNUMERARY NIPPLES IN FINNISH HOME-BRED SHEEP.
}

\author{
Viljo Vainikainen. \\ Zootechnical Institution, University Helsinki.
}

Received 15. II. 1945

In the spring of 1936 Dr. A. Charpentier informed the present writer of the existence of some four-nippled sheep on the Pasture Experiment Station of Selkee under his direction. Later I heard from the then Secretary of the Association of Sheep and Goat Breeding, Mr. P. Suominen, that he also, when travelling about in different parts of the country, had now and then come across sheep, even rams, having more than two nipples. One ewe he had seen had borne up to six nipples. According to the observations of the informant the supernumerary nipples had always been smaller than normal ones.

I have found, in literature, reports on the number of nipples in swine and on the possibilities of increasing this number by deliberate selection. ${ }^{1}$ ) As regards multi-nippled condition in sheep, the present writer has had an opportunity to consult only the report of CASTLE (1) based on observations made by Dr. BeLl. According to him, by selecting for breeding individuals possessing the greatest number of nipples the average number of nipples increased from generation to generation. While in Castle's report the number of nipples had been, in 1890 , on the average 2.27 , it was in 18964.18 and in 1913 correspondingly 5.40. Although, according to Castle Dr. Bell did not make crossing experiments which would have explained the heritability of the factors causing multinippled condition, Castle, nevertheless, on the basis of the above-mentioned observations, considers the dispo-

$\left.{ }^{1}\right)$ By four-nippled sheep such individuals are meant in the following as have borne, in addition to normal nipples, two more or less strongly developed supernumerary nipples. 
sition to supernumerary nipples decidedly heritable. It is not known to me if experiments of the said kind have been performed elsewhere, because owing to the war no English or American literature in the line has reached this country. It is evident, however, that the heritability of multinippled condition in sheep has been only little investigated. Therefore, and as in addition owing to the great fertility of Finnish sheep the genetics of multinippled condition might be of certain economic importance, I began, in 1936, to study the matter experimentally.

Preliminary experiments in crossing were performed at the Pasture Experiment Station at Selkee, Dr. Charpentier having kindly placed the whole sheep material of the station at my disposal. 5 four-nippled and 10 normal-nippled ewes were first bred to a fournippled ram. The parents of the four-nippled individuals used for the experiments had according to checked pedigrees also had four nipples. The rams and ewes produced in the two experiments bore at least four nipples, 2 of the ewes had six. The size of the supernumerary nipples varied in the different individuals considerably, in a manner shown in Table 2. Of the lambs born in the said experiments a breeding ram (No. 1420) was separated for future experiments, an individual with four nipples of about the same size. The choice was influenced also by the fact that the two supernumerary mammae of the dam of the ram were evenly developed and approximately of the size or normal nipples.

In the course of the preliminary experiments it became evident that the Selkee station did not possess sufficient material for such crossing experiments as were necessary for the ascertaining of the number of genes causing the heritability of two supernumerary nipples. It was to be noted also, as an important factor, that Dr. Charpentier had been carrying on, for a number of years already, a successful breeding activity with a view to improving the quality and the quantity of the wool, and that it would have been impossible to conduct a selection aiming at these purposes simultaneously with experiments having as their object the study of the heritability of supernumerary nipples. As, on the other hand, it had not been possible to ascertain correlation between the number of nipples on one hand and the quality and the quantity of wool on the other, a selection made on the basis of only the number of the mammae might before long have thwarted Dr. Charpentier's work. To avoid this I found it advisable to transfer the experiments to another place. 
With the kind support of the late Inspector of Agriculture of the Department in Charge of the Administration of Public Prisons, Mr. A. Jalas, I got permission to begin experiments at the Sukeva estate owned by the said Department. The estate is situated near the town of Kajana and has about 150 home-bred sheep of differen types.

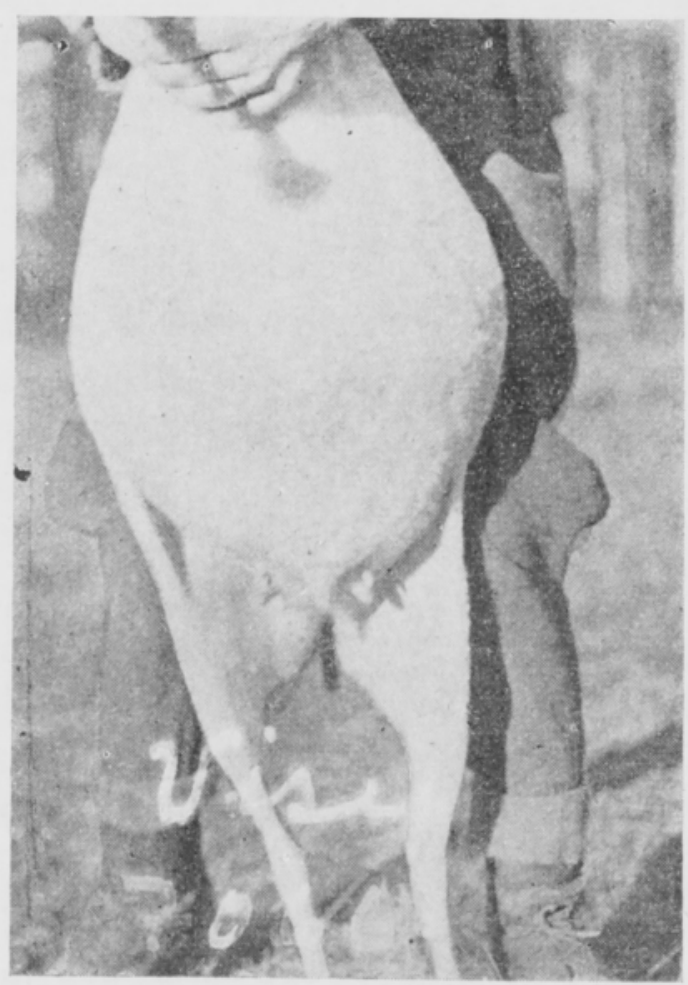

A sheep with supernumerary nipples.

The experiments in the flock of sheep at Sukeva were started in autumn 1938. 31 normal-nippled ewes, in whose families according to records received there had never occurred other than two-nippled sheep, were mated to the afore-said four-nippled ram brought from Selkee. In autumn 193930 of the ewes included in the experiment in the previous year were bred to the same ram. The results have been joined in the Table 1 .

Table $I$.

Mating ठํ N:o $1420(2+2) \times 61$ 우 $(2+0)$

$\mathrm{F}_{1}$ generation had $2+2$ nippled 63 우 and $36 \sigma^{\top}$ (total 99) - $\quad 2+0 \quad 3$ 우 and $1 \sigma^{\nearrow}$ (total 4)

As is shown in the table, $3.8 \%$ of the $\mathrm{F}_{1}$ generation lambs having been two-nippled, the type with supernumerary nipples did 
not dominate. In any case, the result obtained may be considered quite satisfactory. It would have been rather interesting to experiment with the two-nippled sheep born in the F generation by breeding them, but, unfortunately, these individuals had been slaughtered before I was informed, on the front, of their existence.

When the four-nippled lambs of the $\mathrm{F}_{1}$ generation were exami-

\begin{tabular}{|c|c|c|c|c|c|c|c|c|c|c|c|c|c|c|c|}
\hline 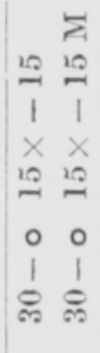 & $\begin{array}{cc}0 & 0 \\
1 & 1 \\
\times & \times \\
1 & 1 \\
0 & 0 \\
1 & 1 \\
20 & 0 \\
0 & 0\end{array}$ & $\begin{array}{cc}\infty & 12 \\
1 & 1 \\
x & x \\
10 & 10 \\
-1 & 9 \\
0 & 0 \\
1 & 1 \\
10 & 10 \\
2 & 9\end{array}$ & 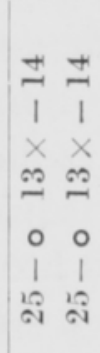 & 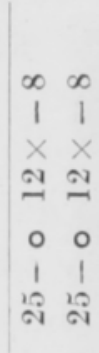 & $\begin{array}{cc}\infty & 0 \\
1 & 1 \\
\times & \times \\
12 & 10 \\
-1 & -1 \\
0 & 0 \\
1 & 1 \\
0 & 0\end{array}$ & 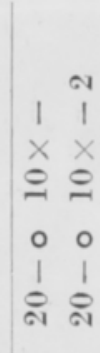 & $\begin{array}{ll}10 & 10 \\
1 & 1 \\
\times & \times \\
0 & 0 \\
0 & 0 \\
0 & 0 \\
1 & 1 \\
0 & 0\end{array}$ & $\begin{array}{cc}\infty & \infty \\
1 & 1 \\
\times & 1 \\
10 & 12 \\
2 & 1 \\
0 & 0 \\
1 & 1 \\
10 & 10 \\
-2 & 9\end{array}$ & $\begin{array}{cc}10 & 10 \\
1 & 1 \\
\times & \times \\
12 & 10 \\
2 & - \\
0 & 0 \\
1 & 1 \\
9 & 0\end{array}$ & 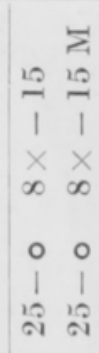 & 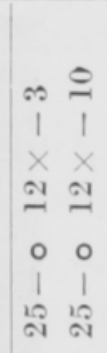 & 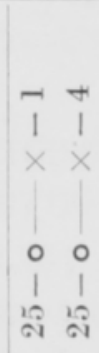 & 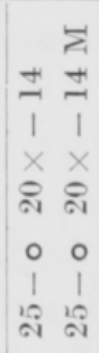 & 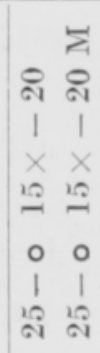 & $\begin{array}{cc}9 & 13 \\
1 & 1 \\
\times & 7 \\
10 & 0 \\
-1 & 0 \\
0 & 0 \\
1 & 1 \\
10 & 20 \\
9 & 0\end{array}$ \\
\hline
\end{tabular}

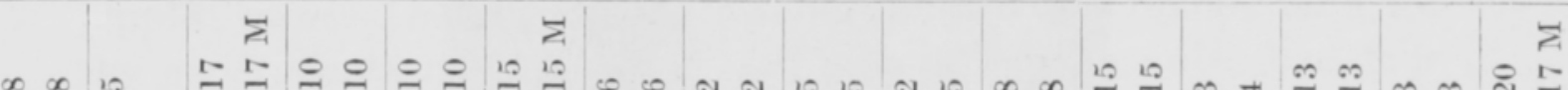

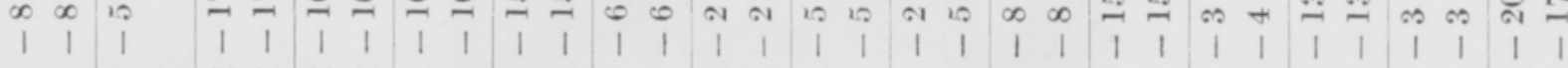

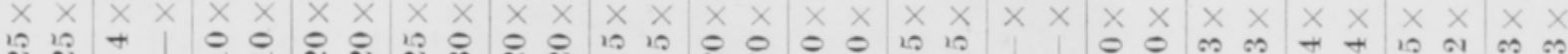

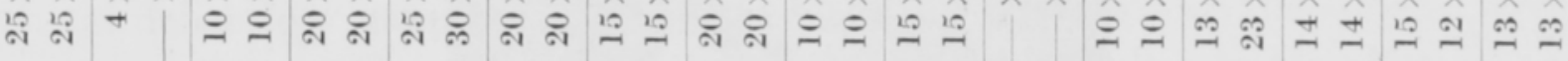

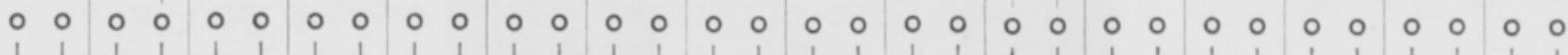

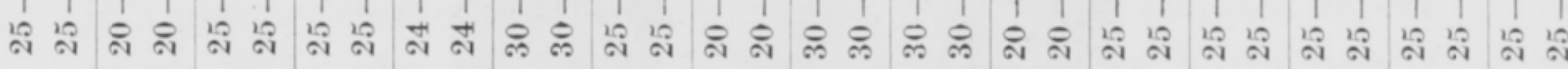
10 10 我

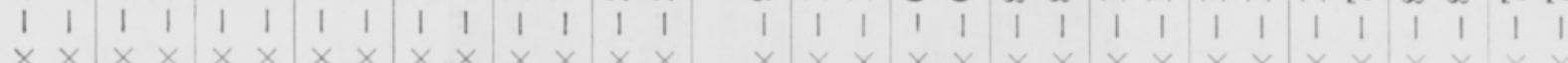

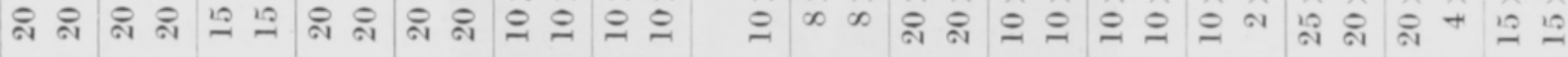

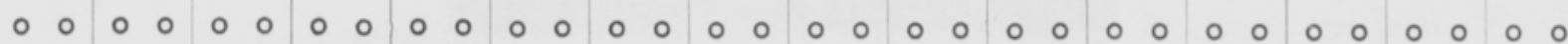
$\begin{array}{llllllllllllllllllllllllllllllll}1 & 1 & 1 & 1 & 1 & 1 & 1 & 1 & 1 & 1 & 1 & 1 & 1 & 1 & 1 & 1 & 1 & 1 & 1 & 1 & 1 & 1 & 1 & 1 & 1 & 1 & 1 & 1 & 1 & 1 & 1 & 1\end{array}$

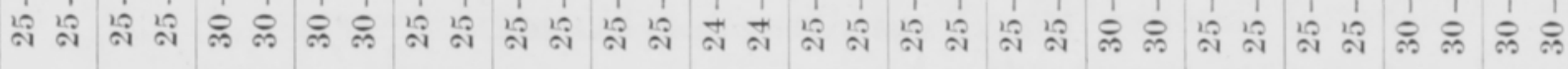

\begin{tabular}{|c|c|c|c|c|c|c|c|c|c|c|c|c|c|c|c|}
\hline 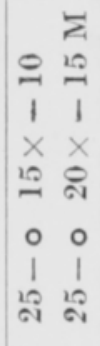 & 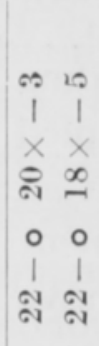 & 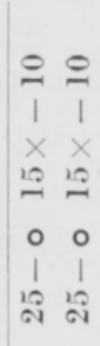 & 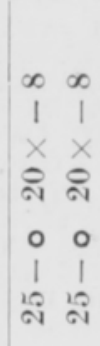 & $\begin{array}{cc}10 & 10 \\
1 & 1 \\
x & x \\
\infty & \infty \\
0 & 0 \\
1 & 1 \\
10 & 1 \\
9 & 9\end{array}$ & 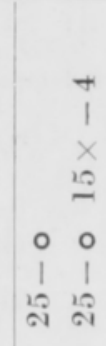 & 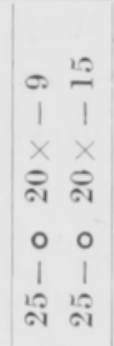 & $\begin{array}{cc}\simeq & 12 \\
1 & 1 \\
\times & \times \\
\underset{\sim}{*} & 0 \\
0 & 0 \\
1 & 1 \\
0 & 0\end{array}$ & 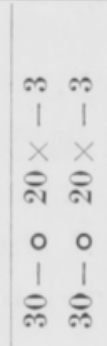 & $\begin{array}{cc}0 & 1 \\
1 & 1 \\
x & x \\
10 & 10 \\
-1 & 9 \\
0 & 0 \\
1 & 1 \\
0 & 0 \\
0 & 0\end{array}$ & 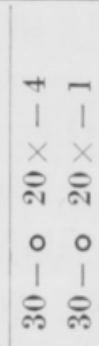 & 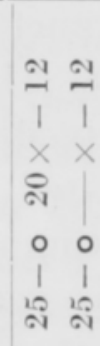 & $\begin{array}{cc}\infty & \infty \\
1 & 1 \\
\times & \times \\
\infty & \infty \\
\propto & \infty \\
0 & 0 \\
1 & 1 \\
\infty & \infty\end{array}$ & 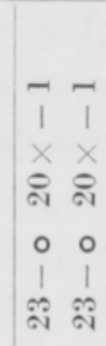 & $\begin{array}{cc}+1 & + \\
1 & 1 \\
x & x \\
12 & 2 \\
-2 & - \\
0 & 0 \\
1 & 1 \\
10 & 10 \\
-1 & 9\end{array}$ & $\begin{array}{cc}12 & 12 \\
1 & 1 \\
\times & x \\
+ & - \\
0 & 0 \\
1 & 1 \\
0 & 0 \\
0 & 0\end{array}$ \\
\hline 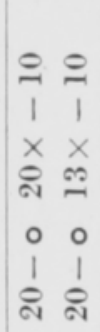 & 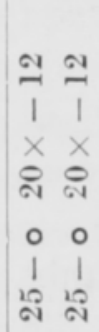 & 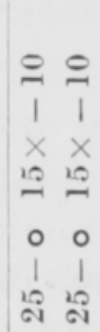 & $\begin{array}{ll}10 & 10 \\
1 & 1 \\
\times & \times \\
+ & 7 \\
0 & 0 \\
1 & 1 \\
0 & 0 \\
0 & 0\end{array}$ & 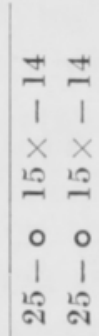 & 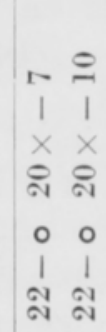 & 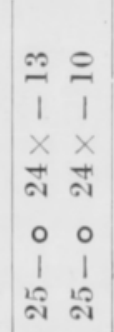 & 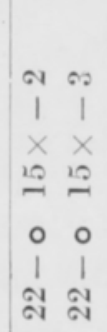 & $\begin{array}{cc}\varrho & \varrho \\
1 & 1 \\
\times & \times \\
\infty & \infty \\
0 & 0 \\
1 & 1 \\
\wp & \stackrel{\rho}{0}\end{array}$ & 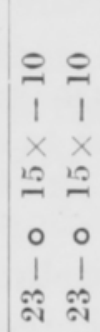 & 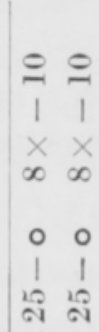 & $\begin{array}{cc}0 & 0 \\
1 & 1 \\
\times & \times \\
12 & 20 \\
- & 2 \\
0 & 0 \\
1 & 1 \\
10 & 10 \\
9 & 9\end{array}$ & 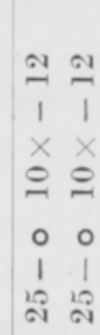 & 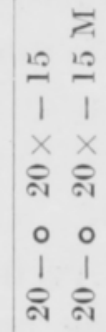 & 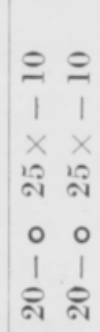 & $\begin{array}{ll} & \bar{\lambda} \\
12 & 2 \\
1 & 1 \\
\times & x \\
0 & 0 \\
0 & 0 \\
1 & 1 \\
0 & 0\end{array}$ \\
\hline
\end{tabular}


ned further, attention was called to the fact that there was considerable variation in the size of the supernumerary nipples, as had been the case also in the preliminary experiments at Selkee. The distance of the supernumerary nipples from the normal nipples was, likewise, very different. It was remarkable, too, that in some of the lambs the supernumerary nipple was not separate but grew as an offshoot by the side of the normal nipple. It was also discovered that duct openings did not exist at the tips of all the supernumerary nipples and that the supernumerary nipples of 10 of the $F_{1}$ ewes yielded milk, the quantity of the mild yielded being, however, according to ocular estimation, considerably under that yielded by normal nipples. In Table 2 some of the lengths of the supernumerary and normal nipples of the $F_{1}$ generation, aged not under one year, are shown, and their distances from each other in millimeters. The entry "M" in the Table denotes an individual producing milk also from the supernumerary nipples.

In Table 2 the circle denotes a normal nipple and a the cross a supernumerary nipple. An offshoot nipple is marked by a crossed line emerging from the circle. The greater figure indicates the length of the normal nipple and the smaller figure the length of the supernumerary or offshoot nipple, and the figure between the circles and the cross the distance between the nipples in question in millimeters. Only quite small lengths have been in question, as is shown in the table, and it is therefore evident that the measurements, though performed by one and the same person with a measuring-stick, are not strictly exact in spite of exactitude having been the object. As it was not among the purposes of the experiment to investigate the differences in the lengths of the nipples, the figures given in the table can be considered sufficiently accurate to show the relation between the lengths of normal and supernumerary nipples.

On account of the participation of the writer in the war it was difficult, in the beginning, for him to direct and to supervise the experiments, but later he was periodically allowed off time to such an extent that plans could again be made for the continuing of the experiments. In the autumn of 194118 ewes, according to perigree so-called pure two-nippled ewes, were mated to the ram No. 259 of the $F_{1}$ generation. At the same time 47 ewes in all of the $F_{1}$ generation were mated to two two-nippled rams which had been ascertained pure in the same way. We find the results of these backcrosses in Table 3 . 
Table 3.

\begin{tabular}{|c|c|c|c|c|c|c|c|}
\hline & \multirow{3}{*}{ Type of making } & \multicolumn{6}{|c|}{ Res u l t s } \\
\hline & & \multicolumn{2}{|c|}{$\begin{array}{c}2+2 \\
\text { nippled }\end{array}$} & \multirow{2}{*}{$\begin{array}{l}\text { To- } \\
\text { tal }\end{array}$} & \multicolumn{2}{|c|}{$\begin{array}{c}2+0 \\
\text { nippled }\end{array}$} & \multirow{2}{*}{$\begin{array}{l}\text { To- } \\
\text { tal }\end{array}$} \\
\hline & & 우 & $\sigma^{7}$ & & 우 & $\delta$ & \\
\hline a) Back-cros & $\mathrm{N}$ :o $\quad 1 \mathrm{P} \sigma^{\top}(2+0) \times 19 \mathrm{~F}_{1}$ 우 $(2+2)$ & 10 & 4 & 14 & 8 & 9 & 17 \\
\hline$\longrightarrow-$ & $\mathrm{N}: 0403 \mathrm{P} \sigma^{x}(2+0) \times 28 \mathrm{~F}_{1}$ 우 $(2+2)$ & 18 & 13 & 31 & 17 & 13 & 30 \\
\hline-1$)$ & $\mathrm{N}$ :o $259 \mathrm{~F}_{1} \sigma^{x}(2+2) \times 18 \mathrm{P}$ 우 $(2+0)$ & 10 & 6 & 16 & 9 & 8 & 17 \\
\hline
\end{tabular}

The table indicates that the back-crosses a and $\mathrm{b}$ have produced $452+2$-nippled lambs in all and 47 lambs having $2+0$ nipples. Their relation $0.96: 1$ corresponds closely to the ratio $1: 1$. Quite close theoretical to the latter comes also, in spite of the meagreness of the material, the ratio $0.94: 1$ yielded by the back-cross. The back-crosses recorded in Table 3 can thus be considered rather favourable.

To investigate the divergence taking place in the $\mathrm{F}_{2}$ generation the No. 259 ram of the $F_{1}$ generation was mated, in autumn 1942, to $27 \mathrm{~F}_{1}$ generation ewes, in all, and in autumn 1943 the same ram sired 35 individuals of the $\mathrm{F}_{1}$ generation. The results are seen in the included Table 4 .

Table 4.

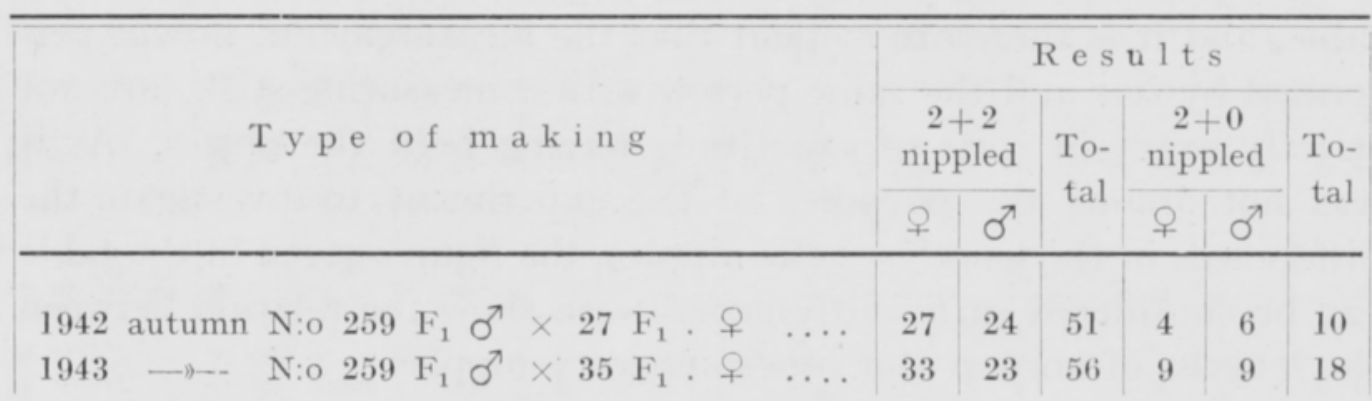

It appears from the Table that the divergence has been about the same in the $F_{2}$ generation in the experiments carried out in the years 1942 and 1943. The summed-up experiment results of the two years show that a total of $1072+2$-nippled ewe and ram lambs were produced and of lambs bearing $2+0$ nipples correspondingly 28. Calculated theoretically, the number of $2+2$-nippled lambs produced ought to have been 101.25 and that of $2+0$-nippled lambs 33.75. The differences in these figures compared with the corresponding figures actually obtained have been, given in the afore-said 
order, -- and +5.75 . The slight difference justifies the conclusion that the two supernumerary nipples examined in the investigation have been caused by one gene.

When I undertook to investigate the heritability of the supernumerary condition of nipples, one of my motives was, as I mentioned in the beginning, a presumption that a number of nipples above the normal could be connected with a certain economic character. The investigation has, however, shown, that individuals bearing supernumerary nipples have not - according to ocular estimation - possessed a greater capacity to produce milk than those having normal nipples. This is in keeping with the results obtained with cattle, according to which it is not possible to estimate the milk production of cows on the basis of the supernumerary nipples of bulls or cows, as was generally believed in the formalistic era. The fact that the distance between the supernumerary and the normal nipples has been very small shows that it is not possible for more than two lambs to suck at the same time, which state of things would have been important considering the great fertility of the Finnish sheep. As, in addition to what has been said above, it has not been possible to ascertain in the investigation a correlation between the number of lambs and a supernumerary condition of nipples, it must be stated, as a final result of the investigation, that a supernumerary condition of nipples has no practical significance in sheep-breeding.

In this connection I wish to record my respectful gratitude to my teacher, Professor H. Federley for the interest he has taken in my investigation and for the valuable advice he has given to me. It is also my pleasant duty to express my deeply-felt thanks to Dr. A. Charpentier for his ready helpfulness manifested in so many ways during the time when the experiments took place on the Selkee Pasture Experiment Station. I beg to thank, further, from my heart, Mr. G. Duwald t, the estate-manager of the Sukeva Central Prison for the varied and untiring help he has given me in the organization and carrying out of the experiments.

\section{REFERENCES}

(1) Castle, V. E. The Genetics of Multi nippled Sheep. Journ. of Heredity 1942, p. 75 . 


\section{SEL OST US.}

\section{KAHDEN LISÄNISÄN PERIYTYMISESTÄ MAATIAISLAMPAALLA.}

V. VAINIKAINEN.

Yliopiston Kotieläintieteellinen laitos, Helsinki.

Tekijän suorittamista risteytyskokeista on ilmennyt, että lisänisäisyys on vallitseva ominaisuus. $\mathrm{F}_{2}$-polvessa on saatu lisănisäisiä ja normaalinisäisiä suhteessa $3: 1$. Eräillä lampailla on lisänisistäkin saatu maitoa. Taulussa 2 pyörylä tarkoittaa normaalinisäă ja × lisảnisää, numerot nisien pituuksia mm:einä ja keskellä olevat luvut normaali- ja lisänisien etäisyyksiä. 